\title{
Appropriateness of omeprazole prescribing in Quebec's senior population
}

\author{
Jean-Pierre Grégoire MPH PhD, Jocelyne Moisan PhD, Isabelle Chabot MSc, Michel Gaudet MSc
}

JP Grégoire, J Moisan, I Chabot, M Gaudet. Appropriateness of omeprazole prescribing in Quebec's senior population. Can J Gastroenterol 2000;14(8):676-680.

BACKGROUND: Prescribing omeprazole for the treatment of digestive disorders accounts for an important part of the costs in Quebec's drug benefit plan. In July 1993, the Quebec drug program listed omeprazole, with restriction, in its formulary. On January 1 , 1994, this restriction was lifted; since then, omeprazole has been listed in the regular provincial formulary.

OBJECTIVE: To describe the appropriateness of initial omeprazole prescribing in the ambulatory senior population of Quebec in the 27 months after being listed without restriction.

SUBJECTS AND METHODS: A retrospective populationbased cohort study was performed using prescription and medical services claims databases of the Quebec drug program. Data were extracted for elderly patients who received their first omeprazole prescription between July 1, 1994 and March 31, 1996.

RESULTS: Among the 47,140 first-time users of omeprazole identified, 7516 (15.9\%) had had an endoscopy in the previous six months, $2308(4.9 \%)$ were given an antimicrobial agent and omeprazole simultaneously, and 22,730 (48.2\%) received omeprazole after prior use of an $\mathrm{H}_{2}$ receptor antagonist (H2RA) or a prokinetic drug. A total of 26,525 (56.3\%) first-time users were prescribed omeprazole based on at least one of the three criteria listed above. Among these users, 729 (2.8\%) received an H2RA concurrently with omeprazole. Altogether, 25,796 (54.7\%) firsttime users received omeprazole appropriately.

CONCLUSIONS: Although reimbursement for omeprazole prescriptions has not been restricted in Quebec since January 1, 1994, it was prescribed appropriately for elderly patients in the majority of cases studied.

Key Words: Administrative database; Appropriateness of prescribing; Drug use review; Elderly patients; Omeprazole

\section{Pertinence des prescriptions d'oméprazole chez les personnes âgées au Québec}

CONTEXTE : Les prescriptions d'oméprazole pour le traitement de troubles digestifs constituent une part importante des coûts du régime d'assurance-médicaments au Québec. En juillet 1993, l’oméprazole était inscrit sur la liste du programme de médicaments du Québec, mais avec certaines restrictions. Ces restrictions ont été levées le $1^{\mathrm{er}}$ janvier 1994. Depuis, l'oméprazole figure sur la liste provinciale des médicaments admissibles. OBJECTIF : Examiner la pertinence des prescriptions d'oméprazole comme traitement initial chez les patients âgés ambulatoires au Québec, et ce, 27 mois après la levée des restrictions.

POPULATION ET MÉTHODE : Une étude rétrospective de cohortes, fondée sur la population a été menée à partir des bases de données du programme de médicaments du Québec pour les demandes de règlement des prescriptions et des services médicaux. Les données recueillies concernaient les patients âgés qui avaient obtenu leur première prescription d'oméprazole entre le $1^{\text {er }}$ juillet 1994 et le 31 mars 1996.

RÉSULTATS : Parmi les 47140 patients ayant obtenu une première prescription d'oméprazole, $7516(15,9 \%)$ avaient subi une endoscopie au cours des six mois précédents, 2308 (4,9\%) étaient soumis à une bithérapie composée d'un agent antimicrobien et de l'oméprazole et 22730 $(48,2 \%)$ prenaient de l'oméprazole après avoir utilisé un inhibiteur des récepteurs $\mathrm{H}_{2}$ ou un agent pro-cinétique. Au total, 26525 patients (56,3\%) se sont vu prescrire de l'oméprazole pour la première fois suivant l'un des trois critères précités. Parmi ces patients, 729 (2,8 \%) prenaient de l'oméprazole en association avec un inhibiteur des récepteurs $\mathrm{H}_{2}$. Dans l'ensemble, la première prescription d'oméprazole s'est avérée pertinente chez 25796 patients $(54,7 \%)$.

CONCLUSION : Même si le remboursement du coût de l'oméprazole ne fait pas l'objet de restriction depuis le $1^{\mathrm{er}}$ janvier 1994, les prescriptions d'oméprazole chez les personnes âgées se sont révélées appropriées dans la majorité des cas étudiés.

Faculté de Pharmacie et Groupe de recherche en épidémiologie, Université Laval, Québec, Québec

Correspondence: Dr Jean-Pierre Grégoire, Groupe de recherche en épidémiologie, Hôpital St-Sacrement du CHA, Quebec, Quebec G1S 4L8.

Telephone 418-682-7511 ext 4664, fax 418-682-7962, e-mail Jean-Pierre.Gregoire@pha.ulaval.ca

Received for publication September 14, 1999. Accepted November 15, 1999 
In Canada's public drug benefit plans, a substantial portion of drug expenditure is attributed to the prescription of gastrointestinal drugs. In Quebec's drug program, gastrointestinal drugs given to elderly patients accounted for $8.5 \%$ of drug costs in 1994, 9.0\% in 1995 and 9.4\% in 1996 (1). During this period, proton pump inhibitors (PPIs) were among the most frequently prescribed classes of gastrointestinal drugs in Quebec.

The first PPI, omeprazole, was approved for the Canadian prescription drug market in 1989. In 1996, omeprazole was the medication with the greatest market share in Canada, with sales of over CDN\$182 million (2).

PPIs are effective in the treatment of many gastrointestinal disorders including peptic ulcers, gastroesophageal reflux disease, Zollinger-Ellison syndrome and Helicobacter pylori infection (3-6). PPIs should be used as first-line agents in the treatment of Zollinger-Ellison syndrome (4,7-10) and moderate to severe reflux esophagitis that is confirmed by endoscopy (11-21). To eradicate $H$ pylori, the use of PPIs in combination with one or more of the following antibiotics for either seven $(22-24)$ or $14(25,26)$ days of therapy has been suggested: amoxicillin, clarithromycin, metronidazole and tetracycline.

Like $\mathrm{H}_{2}$ receptor antagonists (H2RAs), PPIs are a therapeutic option in the treatment of peptic ulcers. However, because an advantage of PPIs over H2RAs is observed mainly in patients with refractory peptic ulcers $(4,27-30)$, studies published before 1996 recommended the restricted use of PPIs as second-line agents in gastric and duodenal ulcers (30-32). Prescribing a prokinetic drug or an H2RA first and restricting PPI use to resistant cases have been recommended for the treatment of uncomplicated gastroesophageal reflux disease $(3,17,20,32-34)$.

Concerned about costs, several provincial drug benefit plans in Canada have listed PPIs with restriction on their formulary. In general, the utilization criteria of these plans allow PPIs to be prescribed as second-line agents only (35). In Quebec, omeprazole was on the restricted formulary from July to December 1993. During this period, before reimbursement could be authorized, omeprazole prescription for elderly patients in an ambulatory setting required a written justification sent by the prescriber to the public drug plan. Payment was made upon acknowledgement of the indication. On January 1, 1994, this restriction was lifted and omeprazole was listed on the regular provincial formulary. After this time, we thought that omeprazole might have been inappropriately prescribed for Quebec's elderly patients.

The objective of the present study was to describe the appropriateness of initial omeprazole prescribing during the 27 months after being listed without restriction for treatment of the ambulatory senior population of Quebec.

\section{SUBJECTS AND METHODS}

A retrospective, population-based cohort study was performed with the use of two databases administered by the Régie de l'Assurance Maladie du Québec (RAMQ) - the prescription and pharmacy services claims database and the medical services claims database. These databases provide information on pharmaceutical and medical services received by Quebec's noninstitutionalized seniors (aged 65 years or over) and welfare recipients. All Quebec seniors who received their first prescription for omeprazole between July 1, 1994 and March 31, 1996 were included in the study population. These first-time users had not filled a prescription for omeprazole in the previous six months.

For each first-time user, prior treatments with an H2RA or a prokinetic drug, and concurrent prescriptions for H2RA were assessed. The H2RA drugs considered were cimetidine, famotidine, nizatidine and ranitidine. The prokinetic drugs considered were cisapride, domperidone and metoclopramide.

Appropriateness of omeprazole prescribing was assessed by using criteria developed after a review of the scientific literature published before 1996. According to these criteria, a first prescription for omeprazole was considered appropriate if the user had had an upper gastrointestinal endoscopy in the previous six months; if the omeprazole was dispensed at the same time as a seven- to 14-day course of antimicrobial therapy with amoxicillin, clarithromycin, metronidazole or tetracycline; or if the omeprazole prescription had been preceded by an H2RA or a prokinetic drug prescription within the previous six months.

However, when an H2RA was used concurrently with omeprazole, the prescription was automatically considered inappropriate. Concurrent use of H2RA was defined as delivery of H2RA within the duration of the first omeprazole prescription. To ensure that prescribing an H2RA was not a change of treatment, a second omeprazole prescription had to be given during the course of the H2RA prescription.

To preserve user anonymity, data transmitted by RAMQ were encoded. Data from prescription claims and medical services claims databases were matched by using patients' individual identifying numbers. Prescriptions and medical services billed between January 1, 1994 and June 30, 1996 were analyzed.

The proportion of Quebec's senior population who received a first omeprazole prescription during the study period was calculated. The proportion of first-time users receiving omeprazole appropriately was also calculated. Variation in the appropriateness of omeprazole prescribing was determined according to prescriber specialty. A $\chi^{2}$ test with an a priori level of 0.05 was used to compare the proportions of appropriate prescribing among prescriber specialties. All analyses were performed using the SAS statistical software package version 6.12 (SAS Institute Inc, USA).

\section{RESULTS}

Between July 1, 1994 and March 31, 1996, 47,140 Quebec seniors received their first prescription for omeprazole; $5.5 \%$ of them were identified as first-time users of omeprazole based on the assumption that the number of seniors eligible for the provincial drug plan in $1995(n=854,280)$ remained constant during this time period.

Among first-time users of omeprazole, 7516 (15.9\%) had 
TABLE 1

Appropriateness of prescribing omeprazole to 47,140 first-time users according to the criteria applied

\begin{tabular}{lc} 
Criteria & $\begin{array}{c}\text { Number of first-time } \\
\text { users of omeprazole (\%) }\end{array}$ \\
\hline $\begin{array}{l}\text { Upper gastrointestinal endoscopy in the prior six months } \\
\text { Yes }\end{array}$ & $7516(15.9)$ \\
No & $39,624(84.1)$ \\
Number of antibiotics* used concurrently & $44,832(95.1)$ \\
Zero & $1537(3.3)$ \\
One & $771(1.6)$ \\
Two & \\
Prior use of an H2RA & \\
Yes & $20,205(42.9)$ \\
No & $26,935(57.1)$ \\
Prior use of a prokinetic drug & \\
Yes & \\
No & $6535(13.9)$ \\
Concurrent use of an $\mathrm{H}^{\dagger} \mathrm{RA}^{\dagger}$ & $40,605(86.1)$ \\
Yes & \\
No & $801(1.7)$ \\
\hline
\end{tabular}

*Amoxicillin, clarithromycin, metronidazole or tetracycline; ${ }^{\dagger}$ Cimetidine, famotidine, nizatidine or ranitidine; ${ }^{\ddagger}$ Cisapride, domperidone or metoclopramide

had an endoscopy in the six months before receiving their first prescription (Table 1). A total of 2308 (4.9\%) seniors were prescribed at least one antimicrobial agent and omeprazole at the same time; 771 of these patients $(33.4 \%)$ received two antibiotics. Combinations of amoxicillin and metronidazole, clarithromycin and metronidazole, and tetracycline and metronidazole were dispensed to 226, 258 and 243 individuals, respectively. The remaining 44 individuals received other combinations of these antibiotics. A total of 22,730 (48.2\%) first-time users of omeprazole received this medication after prior use of an H2RA or a prokinetic drug. Overall, 26,525 (56.3\%) first-time prescriptions of omeprazole met at least one of the three above criteria of appropriate use. However, $729(2.8 \%)$ of these prescriptions were received concurrently with an H2RA prescription. Consequently, 25,796 (54.7\%) first-time omeprazole prescriptions were classified as being appropriate.

General practitioners wrote $70.1 \%$ of first-time omeprazole prescriptions. Appropriateness of prescribing was higher among gastroenterologists. In fact, $71.7 \%$ of omeprazole prescriptions written by gastroenterologists were appropriate compared with $51.8 \%(\mathrm{P}<0.01)$ of those written by general practitioners and $53.6 \%(\mathrm{P}<0.01)$ of those written by internists.

\section{DISCUSSION}

According to our criteria, $54.7 \%$ of first omeprazole prescriptions for the senior population of Quebec were appropriate. This proportion is high, especially when compared with results of other studies performed in Canada (36) or elsewhere
$(37,38)$, and more specifically with the findings of two studies performed around the same time period - one in the ambulatory setting in Ontario (35) and one in the hospital setting in Quebec (39).

McBride et al (35) studied the prevalence of appropriate omeprazole prescribing for the ambulatory senior population of Ontario from April 1992 to March 1993. They determined that only $20 \%$ of Ontario seniors received omeprazole appropriately. When their study took place, omeprazole was in the restricted formulary in Ontario. Thus, an omeprazole prescription for a recipient of the Ontario Drug Benefit program required written justification of the indication by the prescriber, plus acknowledgement of this indication by the pharmacist, before being filled. The Ontario Drug Benefit criteria permitted the prescription of omeprazole after a trial of at least four weeks of an H2RA. Concurring with Ontario's criteria, McBride et al (35) considered a first omeprazole prescription to be appropriate if it was not preceded by an H2RA prescription within one to six months.

In our study, we considered omeprazole prescriptions that occurred less than one month after receipt of a prescription for an H2RA to be appropriate. We used a less stringent criterion because a shorter therapeutic trial may be justified by side effects (36), drug interactions (40) or other relevant clinical factors. Even so, had we defined appropriate prescribing by using the same criterion as that of McBride et al (35), 37.6\% of omeprazole prescriptions for Quebec's seniors would still have been classified as appropriate. Thus, the prescription of omeprazole appears to be more appropriate for Quebec seniors than for Ontario seniors, even without a limited-use program in Quebec. This unexpected difference in the appropriateness of omeprazole prescribing between the two provincial jurisdictions may indicate that restrictive policies do not always succeed in promoting the appropriate use of a drug and that many factors determine the quality of prescribing.

In 1993, the Réseau de revue d'utilisation des médicaments (RRUM) conducted a retrospective review of omeprazole use in 13 hospitals (39). At the time of this review, omeprazole was in the restricted formulary of the provincial drug plan. Altogether, $24 \%$ of the acute treatments with omeprazole were initiated outside the hospital. Results showed that only $45 \%$ of in-hospital prescriptions for omeprazole were appropriate with regard to indications for acute therapy. According to these criteria, use of omeprazole was appropriate for the treatment of duodenal ulcers refractory to H2RA, gastric ulcers confirmed by endoscopy and refractory to H2RA, reflux esophagitis refractory to H2RA or prokinetic drugs, moderate or severe reflux esophagitis confirmed by endoscopy, and Zollinger-Ellison syndrome. The appropriateness of omeprazole prescribing was, therefore, lower in this review of omeprazole use than in the present study. There are many possible explanations for this difference, including variation in population characteristics, variability in physician prescribing habits, discrepancy in length of the studies, and difference in the data collecting methods and indicators of good prescribing practice used. 
In our study, prescribing by general practitioners was significantly more questionable than prescribing by gastroenterologists. In 1991, a similar finding was observed by Moride et al (41) in a study aimed at identifying determinants of suboptimal antiulcer medication use among elderly participants of the Quebec drug plan. One of the predictors for unusually short term use of antiulcer medications was prescribing by a general practitioner. Gastroenterologists may be more familiar with consensus guidelines in their discipline than are general practitioners. Gastroenterologists may also be more likely to prescribe omeprazole as a secondline therapy because they are consulted later in the course of the illness. Further studies should focus on the identification of factors explaining why suboptimal prescribing is associated with the prescriber's specialty.

During the study period, some therapies using a combination of omeprazole and an antibiotic were recommended by, among others, the National Institutes of Health Consensus Development Conference on Helicobacter pylori (26). We considered the concurrent use of omeprazole and amoxicillin, clarithromycin, metronidazole or tetracycline as an indication for $\mathrm{H}$ pylori eradication. Because these antimicrobial agents may be used over seven to 14 days of treatment for a wide array of indications, this particular criterion may have overestimated the appropriateness of omeprazole prescribing. Nevertheless, such overestimation is probably very small because only $4.9 \%$ of patients received their first omeprazole prescription at the same time that they received an antibiotic prescription.

The literature published before 1996 supported the use of omeprazole as a second-line alternative to an H2RA in the treatment of peptic ulcers, and to an H2RA or a prokinetic drug in the treatment of uncomplicated gastroesophageal reflux disease. However, we were unable to assess indication for use, trial duration and posology of former treatment with an H2RA or a prokinetic drug. Therefore, the criteria used to define appropriate second-line therapy as an H2RA or a

\section{REFERENCES}

1. Régie de l'assurance maladie du Québec. Statistiques annuelles 1996. Montreal: Gourvernement du Québec, 1997.

2. Guide de référence académique d'IMS. Information sur les soins de santé au Canada à l'intention des étudiants en pharmacie et de leurs professeurs. Première edition. Pointe-Claire: IMS Canada, 1997.

3. Lampkin TA, Ouellet D, Hak LJ, Dukes GE. Omeprazole: a novel antisecretory agent for the treatment of acid-peptic disorders. DICP 1990;24:393-402.

4. Maton PN. Omeprazole. N Engl J Med 1991;324:965-75.

5. Massoomi F, Savage J, Destache CJ. Omeprazole: a comprehensive review. Pharmacotherapy 1993;13:46-59.

6. Wilde MI, McTavish D. Omeprazole. An update of its pharmacology and therapeutic use in acid-related disorders. Drugs 1994;48:91-132.

7. Lloyd-Davies KA, Rutgersson K, Solvell L. Omeprazole in the treatment of Zollinger-Ellison syndrome: a 4-year international study. Aliment Pharmacol Ther 1988;2:13-32.

8. Maton PN, Vinayek R, Frucht H, et al. Long-term efficacy and safety of omeprazole in patients with Zollinger-Ellison syndrome: a prospective study. Gastroenterology 1989;97:827-36.

9. Rubin W. Medical treatment of peptic ulcer disease. Med Clin North Am 1991;75:981-98.

10. Frucht H, Maton PN, Jensen RT. Use of omeprazole in patients with Zollinger-Ellison syndrome. Dig Dis Sci 1991;36:394-404. prokinetic drug taken in the previous six months may have led to an overestimation of appropriateness.

According to Tamblyn et al (42), the prescription claims database of the RAMQ may be one of the most accurate sources of information on drugs dispensed to individuals. Nevertheless, there are still some limitations to the use of this administrative database in studying ambulatory drug prescribing; for example, most clinical factors that could justify the selection of a drug are not recorded in it. Consequently, only prescriptions that are potentially inappropriate can be screened in a drug use review such as this. To judge definitively the quality of drug use, further indepth review of deviant cases is required. Such a review would likely reveal a higher level of appropriateness of use (43) than was found in the present study.

Since 1996, indications for the use of omeprazole have changed. For instance, prescribing a double therapy for $\mathrm{H} p \mathrm{p}$ lori eradication is no longer supported by the consensus guidelines $(44,45)$; only triple and quadruple eradication regimens are recommended. Further research is needed to evaluate the current quality of omeprazole prescription.

In June 1996, a universal public drug plan was implemented in Quebec; since then, the annual contribution of the elderly to the drug plan has increased. Whether this change in program modalities affected the appropriateness of omeprazole use in Quebec's elderly population is unknown.

The present study suggests that the level of appropriateness of omeprazole prescribing might not be lower in a program where a drug is listed without restriction than in a more controlled environment. In Canada, there is wide variation across provincial drug plans in terms of eligibility, copayments and conditions for reimbursement of drugs in formularies. To what extent this variation translates to the quality of prescribing warrants further research.

ACKNOWLEDGEMENTS: This study was funded by an unrestricted grant from Astra Pharma Inc, Canada.
11. Meuwissen SG, Klinkenberg-Knol EC. Management of gastrooesophageal reflux disease. Are there alternatives to omeprazole? Digestion 1989;44(Suppl 1):54-62.

12. Sandmark S, Carlsson R, Fausa O, Lundell L. Omeprazole or ranitidine in the treatment of reflux esophagitis. Results of a doubleblind, randomized, Scandinavian multicenter study. Scand J Gastroenterol 1988;23:625-32.

13. Jansen JB, Lamers CB. Omeprazole in the short-term treatment of reflux oesophagitis. Digestion 1989;44(Suppl 1):40-6.

14. Howard JM. Omeprazole in the treatment of gastroesophageal reflux disease. Can J Gastroenterol 1989;3(Suppl A):62A-6A.

15. Bate CM, Keeling PW, O'Morain C, et al. Comparison of omeprazole and cimetidine in reflux oesophagitis: symptomatic, endoscopic, and histological evaluations. Gut 1990;31:968-72.

16. Tytgat GN, Nio CY, Schotborgh RH. Reflux esophagitis. Scand J Gastroenterol Suppl 1990;175:1-12.

17. Sontag SJ. The medical management of reflux esophagitis. Role of antacids and acid inhibition. Gastroenterol Clin North Am 1990;19:683-712.

18. Porro GB, Pace F, Peracchia A, et al. Short-term treatment of refractory reflux esophagitis with different doses of omeprazole or ranitidine. J Clin Gastroenterol 1992;15:192-8.

19. Marks RD, Richter JE, Rizzo J, et al. Omeprazole versus $\mathrm{H}_{2}$-receptor 
antagonists in treating patients with peptic stricture and esophagitis. Gastroenterology 1994;106:907-15.

20. Langevin S. Le reflux gastro-oesophagien : pour une approche diagnostique et thérapeutique pragmatique. Le Clinicien 1994;9:51-78.

21. DeVault KR, Castell DO. Current diagnosis and treatment of gastroesophageal reflux disease. Mayo Clin Proc 1994;69:867-76.

22. Jaup BH, Norrby A. Low dose, short-term triple therapy for cure of Helicobacter pylori infection and healing of peptic ulcers. Am J Gastroenterol 1995;90:943-5.

23. Moayyedi P, Sahay P, Tompkins DS, Axon AT. Efficacy and optimum dose of omeprazole in a new 1-week triple therapy regimen to eradicate Helicobacter pylori. Eur J Gastroenterol Hepatol 1995; 7:835-40.

24. Hudson N, Brydon WG, Eastwood MA, Ferguson A, Palmer KR. Successful Helicobacter pylori eradication incorporating a one-week antibiotic regimen. Aliment Pharmacol Ther 1995;9:47-50.

25. Hopkins RJ, Morris JG. Helicobacter pylori: the missing link in perspective. Am J Med 1994;97:265-77.

26. NIH Consensus Conference. Helicobacter pylori in peptic ulcer disease. NIH Consensus Development Panel on Helicobacter pylori in Peptic Ulcer Disease. JAMA 1994;272:65-9.

27. Tulassay Z, Szalay F, Acharya M. Omeprazole versus ranitidine in the treatment of resistant duodenal ulcer. Gut 1992;3:863. (Lett)

28. Bardhan KD. Omeprazole in the management of refractory duodenal ulcer. Scand J Gastroenterol Suppl 1989;166:63-73.

29. Bardhan KD, Naesdal J, Bianchi Porro G, et al. Treatment of refractory peptic ulcer with omeprazole or continued $\mathrm{H}_{2}$ receptor antagonists: a controlled clinical trial. Gut 1991;32:435-8.

30. McQuaid KR, Isenberg JI. Medical therapy of peptic ulcer disease. Surg Clin North Am 1992;72:285-316.

31. Netchvolodoff CV. Refractory peptic lesions. Therapeutic strategies for ulcers and reflux esophagitis that resist standard regimens. Postgrad Med 1993;93:143-4,147-50,153-4.

32. Langman MJS. Omeprazole. For resistant peptic ulcers and severe oesophageal reflux disease. BMJ 1991;303:481-2
33. Hogan WJ. Gastroesophageal reflux disease: an update on management. J Clin Gastroenterol 1990;12(Suppl 2):S21-8.

34. Pope CE II. Acid-reflux disorders. N Engl J Med 1994;331:656-60.

35. McBride JE, Pater JL, Dorland JL, Lam YM. Extent and variation of omeprazole prescribing in an elderly population of Ontario. Ann Pharmacother 1997;31:411-6.

36. Chabot I, Morin J, Bourbeau K, Moisan J. A comparison of retrospective and concurrent drug utilization review of omeprazole. J Pharm Technol 1998;14:202-8.

37. Bashford JN, Norwood J, Chapman SR. Why are patients prescribed proton pump inhibitors? Retrospective analysis of link between morbidity and prescribing in the General Practice Research Database. BMJ 1998;317:452-6.

38. Thors H, Sigurdsson H, Oddsson E, Thjodleifsson B. Survey of prescriptions for peptic ulcer drugs (ACT class AOB2) in Iceland. Scand J Gastroenterol 1994;29:988-94.

39. RRUM. Rapport multicentres: Revue d'utilisation de l'oméprazole. Montréal: RRUM, 1994.

40. Tatro DS, Olin BR, Hebel SK. Drug interaction facts. première ed. St Louis: Facts and Comparisons, Inc, 1993.

41. Moride Y, Melnychuk D, Monette J, Abenhaim L. Determinants of initiation and suboptimal use of anti-ulcer medication: a study of the Quebec older population. J Am Geriatr Soc 1997;45:853-6.

42. Tamblyn R, Lavoie G, Petrella L, Monette J. The use of prescription claims databases in pharmacoepidemiological research: the accuracy and comprehensiveness of the prescription claims database in Québec. J Clin Epidemiol 1995;48:999-1009.

43. Gregoire J-P, Tremblay J. Use of explicit criteria and implicit judgements in a drug-use review program. Am J Hosp Pharm 1987;44:332-6.

44. Hunt R, Thomson ABR, Consensus Conference participants. Canadian Helicobacter pylori Consensus Conference. Can J Gastroenterol 1998;12:31-41.

45. Sadowski DC, Fedorak RN, Bailey RJ, Smith L. Alberta Society of Gastroenterology consensus statement: Helicobacter pylori in peptic ulcer disease. Can J Gastroenterol 1997;11:544-7. 


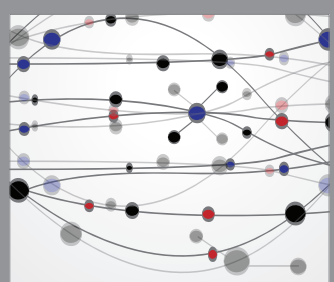

The Scientific World Journal
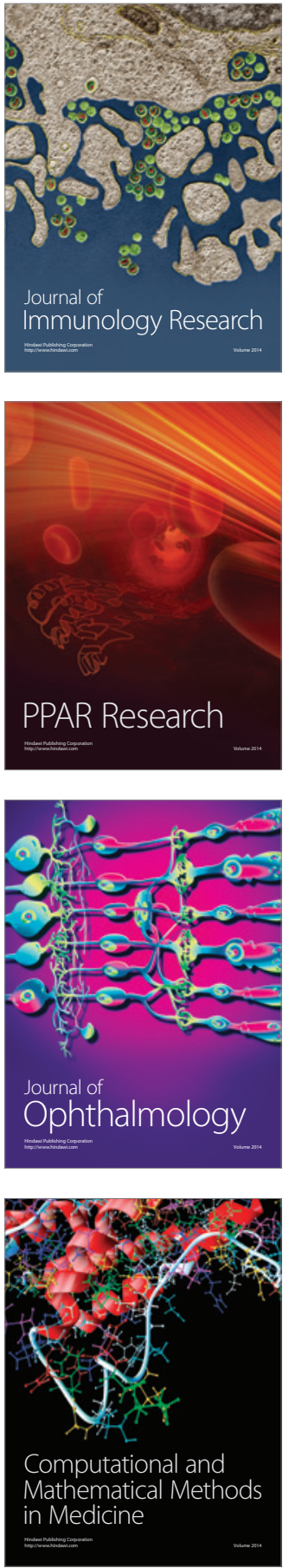

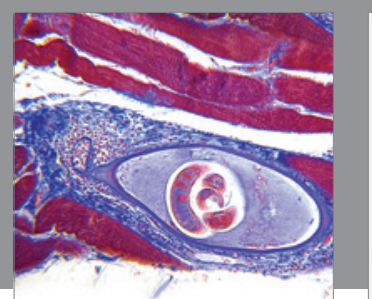

Gastroenterology Research and Practice



\section{Hindawi}

Submit your manuscripts at

http://www.hindawi.com
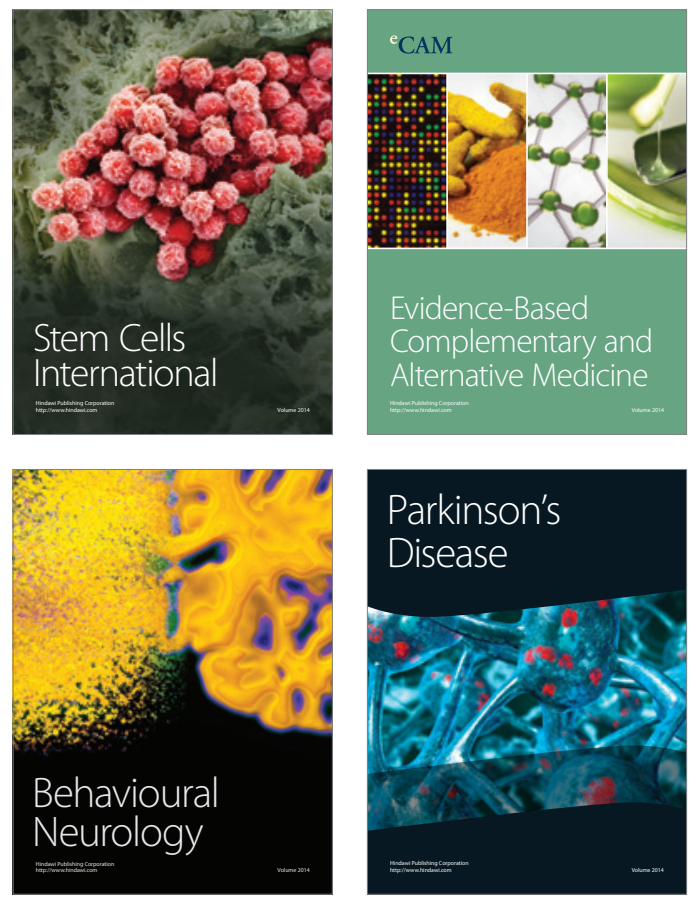


Disease Markers
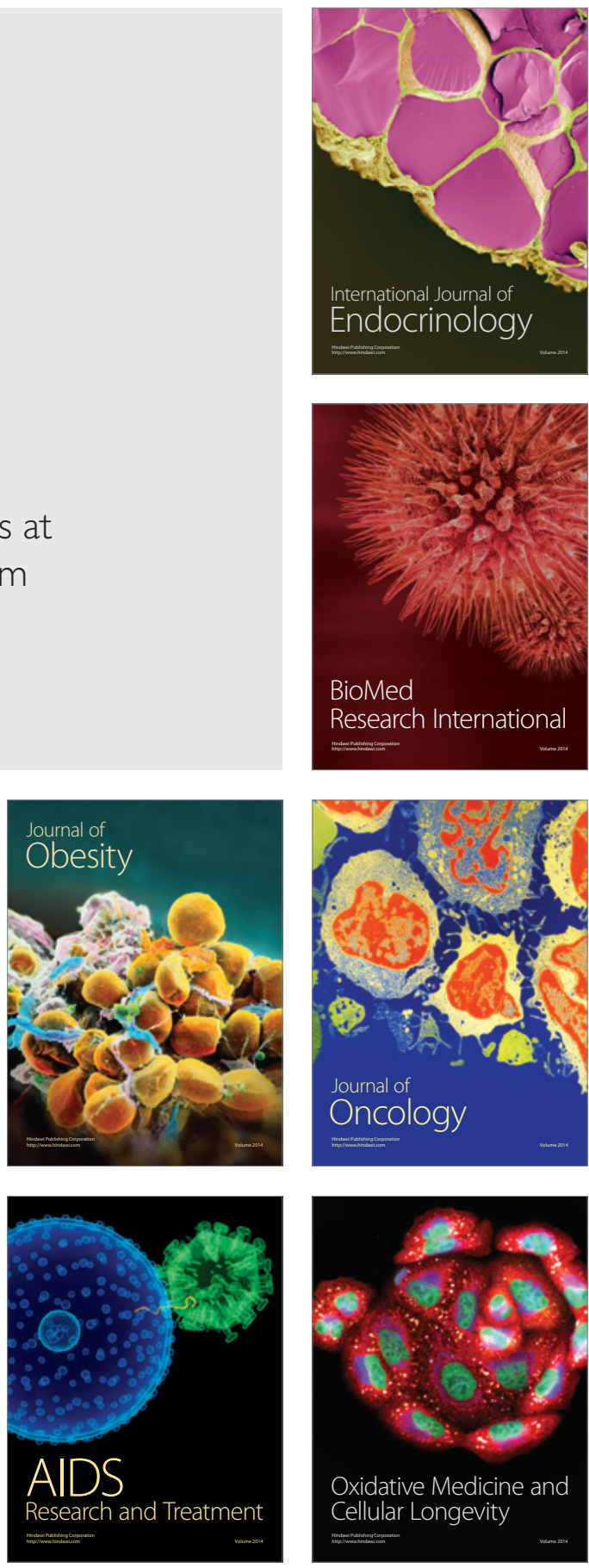